\title{
A mídia e a construção de personagens de autoficção biográfica: uma leitura semântico-lexical de três notícias sobre a morte enigmática de João Guimarães Rosa
}

\author{
The media and the construction of biographical autofiction characters: a semantic-lexical reading \\ of three stories about the enigmatic death of João Guimarães Rosa \\ Camila Moreira Cesar \\ Université Sorbonne Nouvelle/Universidade Federal do Rio Grande do Sul - França/Brasil \\ Marcelo Marinho \\ Universidade Federal da Integração Latino-Americana/Universidade Eötvös Loránd de Budapeste - Paraná/Budapeste - Brasil/Hungria
}

$\diamond$

Resumo: Este artigo propõe-se a analisar a construção de personagens de ficção biográfica em torno da figura pública do escritor João Guimarães Rosa, com base na confrontação de três matérias jornalísticas versando sobre a morte enigmática do romancista, ocorrida em 19 de novembro de 1967. Cabe ressaltar que, em 2017, celebram-se 50 anos desse evento marcante da cultura brasileira, ainda por se decifrar em todo seu alcance e significação. Por esse viés, o presente estudo parte igualmente do fato de que Grande Sertão: Veredas é qualificado, por seu próprio autor, como uma "autobiografia irracional": trata-se, de maneira inédita na história da literatura, de contar uma vida (e uma morte), para em seguida vivê-la. Por esse viés, a análise centra-se na dimensão narrativa do texto jornalístico, no plano das imbricações entre universo fático e universo ficcional (MOTTA, 2005). Com esteio em um corpus constituído por três artigos publicados no $O$ Globo, O Estado de São Paulo e Folha de São Paulo, discorre-se sobre os índices semântico-lexicais e as condicionantes editoriais (CHARAUDEAU, 2010) que induzem a consolidação de diferentes relatos proto-biográficos em torno da imagem de Guimarães Rosa, romancista que, por sua vez, é artífice e demiurgo consciente de suas próprias personas (no sentido junguiano do termo), ou suas personagens de autoficção biográfica categoria poética que solicita o aprofundamento de reflexões teórico-críticas. No presente caso, a notícia biográfica constrói-se com apoio em recursos poéticos, por meio de um discurso em que, articulando-se mutuamente, convergem literatura e jornalismo. Interroga-se, por fim, o papel do jornalismo enquanto construtor de personagens, em sua dimensão de representações sociais, como no caso da imagem de pessoas públicas, assim como as formas indiciais de indução ficcional que certos sujeitos podem exercer sobre os jornalistas e seus veículos, como forma de ampliar e consolidar a difusão de uma obra literária por meio de um personagem biográfico que seduz a atenção do leitor para muito além do último capítulo.

Palavras-chave: João Guimarães Rosa; Jornalismo e literatura; Autoficção; Personagem de ficção

\begin{abstract}
This article proposes to analyze the construction of characters of biographical fiction around the public figure of the writer João Guimarães Rosa, based on the confrontation of three journalistic articles dealing with the enigmatic death of the novelist, that occurred on November 19,1967 . It is worth mentioning that, in 2017, 50 years of this remarkable event of Brazilian culture are celebrated, still to be deciphered in all its scope and significance. From this bias, the present study also starts from the fact that Grande Sertão: Veredas is qualified, by its own author, as an "irrational autobiography": it is unprecedented in the history of literature to tell a life (and a death), and then live it. By this bias, the analysis focuses on the narrative dimension of the journalistic text, on the level of imbrications between the factual universe and the fictional universe (MOTTA, 2005). With a corpus of three articles published in O Globo, O Estado de São Paulo and Folha de São Paulo, the semantic-lexical indexes and the editorial constraints (CHARAUDEAU, 2010) are presented, which induce the consolidation of different protobiographical reports around the image of Guimarães Rosa, a novelist who, in turn, is a conscious artist and demiurge of his own personas (in the Jungian sense of the term), or his characters of biographical autofiction - a poetic category that calls for a deepening of theoretical-critical reflections. In the present case, the biographical news is constructed with support in poetic resources, through a discourse in which, by articulating each other, literature and journalism
\end{abstract}


converge. Finally, the role of journalism as a character builder is questioned, in its dimension of social representations, as in the case of the image of public persons, as well as the indicial forms of fictional induction that certain subjects can exert on journalists and their vehicles as a way to broaden and consolidate the diffusion of a literary work through a biographical character that seduces the reader's attention well beyond the last chapter.

Keywords: João Guimarães Rosa; Journalism and literature; Autofiction; Fiction character

\section{Considerações iniciais}

Em mais uma de suas fulgurantes intuições, Michel Foucault sustenta a ideia de que Dom Quixote, o célebre personagem de Cervantes, encilha seu cavalo e lê o mundo para demonstrar os livros. A mediação de textos para o conhecimento do mundo pode se apresentar, nesse caso, como o ponto de convergência entre jornalismo e literatura. No presente estudo, buscamos percorrer um caso exemplar de biografia na cultura brasileira: João Guimarães Rosa. O romancista morreu em 19 de novembro de 1967, um domingo - três dias após tomar posse na Academia Brasileira de Letras, um evento temerosamente adiado durante quatro anos. Assim, buscaremos explicitar os esquemas narrativos por cujo intermédio a imprensa imediatamente noticiou esse fato, tornando-se mediadora para o conhecimento de uma realidade que escapa ao domínio do entendível ou do explicável. Da mesma forma, interrogaremos em que medida essas notícias terminam contribuindo para a construção de uma ficção biográfica, cujo enredo desenrola-se no âmbito da indecidibilidade dos sentidos. Nessa perspectiva, nosso trabalho estrutura-se segundo três eixos hermenêuticos: no primeiro momento, lançamos um olhar recapitulativo sobre estudos que discorrem sobre a dimensão narrativa do discurso jornalístico; em seguida, analisamos as condicionantes contextuais e editoriais que (pré)determinam a transmutação de um fato em um texto midiático; por fim, com base nos campos lexicais e por meio da análise discursiva, chegaremos aos esquemas narrativos que, tal como na literatura ficcional, cristalizam a imagem de um personagem (ou persona) -no presente caso, um personagem biográfico que participa ativamente do processo de construção desse mesmo discurso jornalístico.

\section{A mídia e a construção de sujeitos ficcionais}

"When a dog bites a man that is not news, but when a man bites a dog that is news". Atribuído a John B. Bogart (1848-1921), esse célebre aforismo sintetiza a lógica de seleção de fatos com elevado grau potencial de interesse jornalístico: a aderência com fatos de ficção. Ora, por intermédio da notícia, o leitor busca informar-se sobre a realidade para melhor situar-se no mundo. Assim, resultando de uma série de procedimentos rotineiros que caracterizam o modus operandi do campo, o discurso jornalístico é a modalidade discursiva convencionalmente chamada a refletir, de forma quase sincrônica, sobre os fatos cotidianos. Quais seriam, nesse contexto, as relações entre fato e ficção, entre seres empíricos e personagens ficcionais?

Partindo da ideia consensual de que o rigor e a precisão são os requisitos e pressupostos éticos fundamentais no que se refere ao tratamento das informações, Daniel Cornu (1998) assim distingue a pesquisa jornalística da histórica: enquanto esta atenta sobretudo para a relação diacrônica entre os fatos, aquela propõe uma avaliação em forma de notícias cenarizadas, imediatamente após a ocorrência do fato. Para esse jornalista e acadêmico dedicado à ética informativa, "a informação jornalística coloca em jogo realidades e acontecimentos, que constituem a matéria-prima para a construção de sentidos e de estilos. Ela inclui fatos, comentários e narrativas. Estes correspondem a três atos distintos: a observação, a interpretação e a narração - os quais se apresentam como os três elementos constitutivos da identidade jornalística" (CORNU, 1998, p. 14, tradução nossa).

O discurso jornalístico corresponderia, por esse viés, a uma modalidade de representação da realidade, uma construção simbólica realizada por intermédio de palavras - tal qual a literatura de ficção, por exemplo. Nesse processo, o jornalista torna-se um ator no processo de construção de sentidos para o fragmento de realidade que escolheu re-presentar segundo um ângulo específico, dentre outros tantos possíveis. Nesse sentido, se a informação é um trabalho de linguagem e de perspectiva, quais são os limites da objetividade do discurso jornalístico? No âmbito de uma "lógica instrumental" confrontada a relações sociais de conflito, negociações e interações, caberia portanto perguntar, com Denis Ruellan e Gérard Cornu (1993), em que medida a "tecnicidade intelectual" dos jornalistas, devidamente codificada em convenções, poderia oferecer garantias suficientes para uma suposta tradução fiel da realidade, seja ela transcendente ou cotidiana?

Compreendendo a informação como o resultando de um ato de comunicação, Patrick Charaudeau (2010) 
destaca o papel central da linguagem na estruturação da informação sob forma de discursos. Segundo o autor, "a linguagem não se refere somente aos sistemas de signos internos a uma língua, mas a sistemas de valores que comandam o uso desses signos em circunstâncias de comunicação particulares" (CHARAUDEAU, 2010, p. 33). A informação pode ser assim entendida como linguagem em forma de discurso, normatizado pelas instâncias sociais. Por sua vez, o discurso é o instrumento que permite a organização dos fatos e a circulação da notícia, indutora de produção de sentidos junto a uma comunidade.

No que concerne à informação do tipo midiática, Charaudeau (2010) indica a existência de três instâncias ("lugares") de produção de sentido que articulam o jogo de co-intencionalidades entre efeitos visados, efeitos possíveis e efeitos produzidos: a) instância de condições de produção (definida por fatores econômicos, temporais, editoriais e socioculturais); b) instância de construção do produto (definida por aspectos semióticos, linguísticos e discursivos de enunciação e recepção); e c) instância de recepção (público-alvo, abstrato e imaginado; e público-leitor, concreto e efetivo). Dessas ideias, e para acompanhar Stuart Hall (1994), podemos inferir que o jornalista é um ator essencial no processo de tradução da informação em forma de discurso suscetível de induzir uma multitude de decodificações possíveis.

Esse breve panorama sobre a complexidade do tratamento, produção e recepção da informação revela uma dupla concepção do jornalismo enquanto ferramenta para o conhecimento do mundo. Por um lado, na esteira aberta por Public Opinion (1922), de Walter Lippman, concebe-se o jornalismo como instrumento para a construção de realidades, instância responsável pela seleção, tratamento e divulgação daquilo que devemos saber e conhecer, numa direção norteadora dos saberes socialmente compartilhados. Pela vertente oposta, numa perspectiva emprestada dos estudos literários para a análise do discurso jornalístico em sua dimensão mitológica (BIRD e DARDENNE, 1993), toma-se o jornalismo como uma forma de narrativa, em sua função de molde (ou "fôrma" - sic) para a compreensão do mundo. No presente estudo, busca-se articular ambas as perspectivas, sobretudo no que tange à seleção de índices factuais para a construção da notícia jornalística.

No que se refere ao jornalismo como narrativa, observam-se profundas imbricações entre o fático e o fictício. O relato de um acontecimento porta uma primeira etapa de descrição, seguida por outra de explicação e uma última de reações. Esta cadeia de ações tem seu estopim na mise en scène discursiva que constrói a narrativa, nomeando o conhecimento a ser partilhado, integrando-o de maneira coerente dentro de uma história que, tal como na literatura, possui um início, um meio e um fim - mesmo que o enredo poético submeta-se ao princípio da indecibilidade de sentidos, segundo propõem Jacques Derrida e Paul Ricoeur. Como veremos ao longo deste trabalho, mesmo uma narrativa jornalística pode se apresentar nos moldes desse princípio, sobretudo no que se refere à invenção de personagens que sobrexistem entre o fato e a ficção.

Nessa perspectiva, Patrick Charaudeau (2010) chama a atenção para o fato de que o sentido nunca é dado antecipadamente: a transmutação de um "mundo a significar" em um "mundo significado" resulta de uma construção discursiva originária de um narrador que conta a história a partir de um determinado ponto de vista. No que tange às chamadas "comunidades interpretativas" formadas pelos jornalistas (TRAQUINA, 2008), essa produção de sentido se opera numa via de mão dupla: esses profissionais são responsáveis por localizar, contextualizar e direcionar os debates no espaço público, ao mesmo tempo em que manejam um amplo capital cognitivo para o entendimento e a compreensão iniciais dos fatos cotidianos.

Gislene Silva (2005) propõe o conceito de "jornalismo cardinal" para qualificar essa dupla capacidade de produção de sentido. Apreendendo o jornalismo em sua dimensão simbólico-mítica a partir dos meios linguísticos e semânticos utilizados para descrever a realidade, a autora identifica quatro pontos norteadores da lógica narrativa jornalística: as informações que vem do leste (isto é, da direita, do principal envolvido, do sujeito originário do fato), do oeste (da esquerda, consistindo nos demais envolvidos, nas circunstâncias afetadas), do sul (remissão ao passado, comparação, pistas de compreensão) e do norte (projeção para o futuro, explicação, conclusão). A informação jornalística e sua estruturação em forma discursiva seria, assim, uma matriz significadora que serve de base para compreender o mundo. Tais ideias serão fundamentais para se analisar, neste estudo, as articulações entre Guimarães Rosa e a plêiade de jornalistas que se propõem a coletar, selecionar, interpretar e divulgar informações biográficas cujas fontes são, no mais das vezes, o próprio romancista.

Considerando assim o jornalismo como uma espécie de molde para a representação realidade, alguns autores vão inclusive sublinhar a ideia de que, para muito além da busca cotidiana pelo novo e pelo inédito, a lógica jornalística orienta-se mais apropriadamente pela busca de uma diversidade que se repita no âmbito de estruturas reconhecíveis pelo leitor, confirmando um certo conhecimento prévio sobre o mundo, como bem relembra Gislene Silva (2005). Por outro lado, Gaye Tuchman (1972) vai discorrer sobre um "ritual estratégico 
de objetivação" por parte dos jornalistas, para analisar as lógicas profissionais do plano nos processos de escolha e de enquadramento das informações, de modo a atribuir-lhes um sentido que também seja facilmente reconhecível pelos leitores.

Esses processos jornalísticos conformam-se, primeiramente, em função dos fatores determinantes do valor-notícia, um critério que é definido por características marcantes do acontecimento que se vai narrar (ou negligenciar sob o peso do silêncio), no que se refere à sua relação imediata com o público leitor: proximidade geográfica e temporal, ineditismo, condição fúnebre ou catastrófica do evento, situações limite ou conflituosas, ações inesperadas, impacto das consequências (social, econômico, psicológico etc.), significância existencial, entre outros. Os fatores definidores do valor-notícia são múltiplos e variáveis, pois dependem de inúmeras condições contextuais, tal como explanam Mauro Wolf (2002) e Nelson Traquina (2005), por exemplo, entre os diversos pesquisadores que se debruçam sobre esse aspecto crucial para as teorias da comunicação. Contudo, os procedimentos protocolares de seleção de fatos e escolha de um ângulo de ataque são considerados, por vezes, como índices suficientes para demonstrar a imparcialidade e a objetividade no tratamento das informações. Em todo caso, tal metodologia de trabalho integra a retórica profissional no campo jornalístico, lugar de produção de narrativas sobre aquilo que se compreende como realidade, como veremos mais adiante no tangente às notícias sobre a morte de João Guimarães Rosa. Entrementes, vale registrar o espanto irônico de Nelson Rodrigues com o tratamento dispensado pela imprensa da época à "morte natural" do romancista mineiro:

súbito, num domingo, morria Guimarães Rosa. A notícia deu-me um alívio, uma brusca e vil euforia. É fácil admirar, sem ressentimento, um gênio morto. Já tínhamos um Machado de Assis. Guimarães Rosa seria outro Machado de Assis. [...] No dia seguinte [à morte], Guimarães Rosa tinha uma imprensa de chefe de Estado assassinado. Vocês se lembram quando um tiro arrancou o queixo forte, vital, de Kennedy? Pois Guimarães Rosa subiu às manchetes como o presidente fuzilado dos Estados Unidos. Pela primeira vez um escritor aparecia em oito colunas, nas primeiras páginas. No princípio do século, Euclides da Cunha também teve a mesma glória impressa. [...] Há qualquer coisa de árido, ou de vazio, ou de humilhante, na morte natural do grande homem. Pois Guimarães Rosa, com um puro e convencional enfarte (sic), mereceu a promoção frenética das tragédias de sangue. Repito: - pela primeira vez fez-se crítica literária nas manchetes. Os meus amigos penduravam-se no telefone. [...] Quanto a mim, fui ao velório na Academia (RODRIGUES, 1993, p. 23-24).
Por essa vertente, caber acrescentar, com Luiz Gonzaga Motta (2005, p. 2), que a narrativa é o ato de "descrever algo enunciando uma sucessão de estados de transformação". Esse autor aborda o processo de construção da notícia de um ponto de vista da antropologia, considerando o jornalismo como narrativa e utilizando a narratologia como aporte metodológico. Para Motta, "o discurso narrativo literário, histórico, jornalístico, científico, jurídico, publicitário e outros participam dos jogos de linguagem, todos realizam ações e performances socioculturais, não só relatos representativos" (MOTTA, 2005, p. 3).

No plano jornalístico ou literário, diversos estudiosos da comunicação (LAGE, 2005; LYRA, 1980; MEDINA, 2003; OLINTO, 2008; MOTTA, 2005) sublinham a polimorfia das narrativas midiáticas que, como construções híbridas, articulam elementos fáticos e fictícios para promover a necessária produção de efeitos de sentido. No que tange ao discurso jornalístico e, mais precisamente, no que se refere à sua dimensão narrativa, podemos compreendê-lo como uma cadeia solidamente articulada de jogos de linguagem, que induzem a construção de significados em um dado contexto, culturalmente definido. Assim como na literatura, o jornalismo também precisa criar estratégias em torno de seus personagens para que o leitor possa acompanhar a lógica da apresentação dos fatos, a fim de tornar inteligível algo que escapa aos sentidos, ou domesticar os fatos que poderiam parecer excessivamente estranhos, ilógicos, incompreensíveis. Nesse sentido, para glosar Paul Ricoeur (1983), pode-se dizer que narrar significa explicar, aproximar o diferente e o diverso, explicitar a relação entre os agentes, as razões de agir, as causas e consequências que se situam em lugares e tempos particulares. Claro está, os personagens implicados são de essencial importância para a credibilidade ou verossimilhança da notícia.

Luiz Motta (2005) destaca ainda o papel da narrativa como forma de identificação em um mundo no qual a vida individual ou coletiva é cada vez mais narrativizada. Nessa perspectiva, podemos aqui falar de narrativas construídas dentro de diferentes "quadros de experiência social", como bem analisa Erving Goffman (2012): segundo esse autor, no plano definido por esses quadros, interpretamos diferentes papéis em função do contexto, operamos escolhas fundamentais de teatralização de nosso self (representação do eu) dentro do leque de possibilidades que nos oferece a vida cotidiana. Por esse viés, cabe notar que Carl Gustav Jung (1981) assim definia a importância da imprensa (logo, dos efeitos do discurso sobre a realidade) na construção desses sujeitos narrativos que são as "personas", já no longínquo ano de 1917(!): para o psicanalista, toda vocação e toda profissão comportam personas características, que lhes 
são próprias; já no primeiro quartel do século $\mathrm{XX}$, com a assunção vertiginosa da imprensa e da fotografia, tornouse mais fácil estudar esse fato social, sobretudo no caso das personalidades públicas. O mundo exige a adoção de certas formas de comportamento, e mesmo no âmbito de profissões, certos arquétipos terminam por se suplantar sobre a natureza primeira do indivíduo: tome-se como exemplo o professor com seu livro-texto, ou o tenor com sua voz característica, acrescenta o psicólogo de Viena. $\mathrm{Ou}$, no caso que nos compete analisar, observem-se as fotografias de João Guimarães Rosa cuja concepção, produção e divulgação foram promovidas ou induzidas pelo próprio autor à partir de sua proximidade com fotógrafos e jornalistas de expressão.

Nesse contexto teórico, uma persona corresponde a uma imagem de si, à qual o sujeito atribui estatuto de verdade e toma para si próprio, ou, pelo viés oposto, apenas oferece à degustação alheia - condição que implicaria a emergência de uma outra persona: ironicamente farsesca ou francamente enganadora. No interesse do presente estudo, adotaremos, com Jung (2014), a seguinte definição para o conceito que ora nos ocupa: uma "persona" resulta de um intricado sistema de inter-relações que uma consciência individual entretém com o meio social em que vive, moldando uma espécie de máscara destinada a causar uma impressão predefinida pelo sujeito, ao mesmo tempo em que sonega a verdadeira natureza que esse indivíduo enxerga em si próprio. Uma "persona" reflete, no mais das vezes, um personagem de ficção - tal como ocorre na trama autoficcional que buscamos desentranhar.

Assim, de forma consciente ou automatizada, os jornalistas, em sua condição privilegiada de narradores da era tecnológica da "idade mídia", como bem os definiu Christa Berger (2002), também vão integrar em suas operações rotineiras estratégias discursivas que induzem a emergência de uma rede de conexões entre os diferentes sujeitos que fazem parte desse amplo enredo narrativo. Os arquitetos da notícia materializam, assim, por meio da palavra, horizontes de significação que resultam de “(...) relações que se estabelecem por causa da cultura, da convivência entre seres vivos com interesses, desejos, vontades e sob os constrangimentos e as condições sociais de hierarquia e de poder" (MOTTA, 2005, p. 3).

De forma geral, os escritores (entre outros artistas) demonstram perfeita consciência da importância da instância midiática para alcançar esse objetivo em seus campos de atuação, para cristalizar uma imagem de si e, igualmente, de sua obra. Na esteira aberta pelo crescente interesse da comunidade acadêmica sobre o tema, cabe registrar a emergência da revista australiana Persona Studies, com um número dedicado exclusivamente ao estudo de personas do mundo artístico, em 2016, enquanto a próxima edição é consagrada às personas políticas. Ou a revista holandesa Kunstlicht, com um número dedicado integralmente às personas artísticas, em 2015. Nesse tocante, cabe lembrar-se ainda das fotografias de Jorge Amado ao pé de coqueiros, Frida Kahlo em seu leito de enferma, Jorge Luis Borges em suas bibliotecas, ou Manoel de Barros em seu despojamento pantaneiro, por exemplo. Também caberia mencionar as múltiplas personas construídas publicamente por ícones da indústria cultural, tais como David Bowie, Madonna ou Lady Gaga (WINDEN e BARTHOLOMEW, 2015). Nessa perspectiva, cabe lançar um olhar atento sobre as aludidas fotografias deixadas à posteridade pelo romancista mineiro.

A consciência da condição narrativa na construção das personas públicas pode ser entrevista, por exemplo, na célebre viagem pelo Sertão que Guimarães Rosa realizou, em 1952, na companhia de Eugênio Silva, fotógrafo encarregado de registrar o acontecimento para publicação na revista $O$ Cruzeiro (edição de 21 de junho de 1952). As fotografias apresentam-se como imagem testemunhais de um escritor engajado em favor da cultura brasileira, sobretudo a sertaneja, cuja condição exótica - no que se refere a um leitor urbano ou estrangeiro torna-se um importante elemento para a construção de uma certa persona literária, essencial para o sucesso editorial do autor de Grande Sertão: Veredas, assim como de todo e qualquer escritor. Excepcionalmente, Rosa troca sua tradicional gravata borboleta por roupas de vaqueiro, induzindo a emergência de um horizonte de espera para sua obra, que poderia ser interpretado na esteira desta afirmação do escritor, em carta enviada a seu pai: "O detalhe é muitas vezes de grande proveito, pois metido num texto dá impressão de realidade" (ROSA, 1983, p. 174). É evidente que esses detalhes fotográficos balizam uma certa leitura para o conjunto da obra roseana, pelo viés regionalista, historiográfico ou documental - pista de leitura ou camuflagem poética?

$\mathrm{Se}$, como querem os formalistas russos, a literatura ficcional busca causar efeitos de estranhamento junto ao público leitor, o jornalismo, por outro lado, busca domesticar o estranho por meio de imagens que possibilitem o imediato reconhecimento do real por parte dos leitores. Ora, cabe então a pergunta: como um autor do porte de Guimarães Rosa poderia se servir de imagens domesticadas para provocar efeitos de estranhamento sobre sua própria morte física? Essa é a questão que passamos agora a explorar, nas articulações entre mídia e fatos biográficos, no que se refere às formas pelas quais o romancista e diplomata João Guimarães Rosa ludibria a todos, ou quase, no âmbito da construção narrativa de uma biografia ambígua, em que se mesclam o fático e o fictício, a domesticação e o estranhamento, o ser empírico e o personagem de ficção. 
Para nosso percurso interpretativo, o corpus de análise foi definido em função da ampla circulação e do significativo número de leitores dos veículos selecionados para o presente estudo: os jornais $O$ Globo, O Estado de São Paulo (Estadão) e Folha de São Paulo, em suas edições publicadas imediatamente após o anúncio da morte do romancista em 19 de novembro de 1967, uma vez que trazem uma retrospectiva dos feitos biográficos e, por esse viés, contribuem para a consolidação da imagem da(s) persona(s) pública(s) - personagens bioliterários. Essas matérias encontram-se nos acervos digitais dos supracitados veículos informativos. É útil notar que o falecimento de Rosa foi atestado às $20 \mathrm{~h} 31 \mathrm{~min}$ do domingo, no Rio de Janeiro, e somente o jornal sediado naquela cidade incluiu uma matéria na edição lançada na madrugada do dia seguinte, segunda-feira, 20 de novembro. Os veículos da cidade de São Paulo publicaram a notícia com relativo atraso, em suas edições de terça-feira.

No que se refere à metodologia de análise das condições midiáticas de produção e recepção de notícias, o presente trabalho se baseia sobretudo nos aportes teóricos sistematizados por Patrick Charaudeau (2010). De forma complementar, utilizaremos igualmente as ferramentas conceituais propostas por Luiz Gonzaga Motta (2005). A metodologia de análise discursiva inclui ferramentas da literatura comparada, sobretudo aquelas sistematizadas por Anne François e Yen-Maï Tran-Gervat (2010) em seu compêndio publicado pela Sorbonne. Assim, centraremos nossos esforços na busca de significados para aspectos como o destaque dado às matérias (posição e espaço no espelho do jornal, imagens ilustrativas, articulação com o peritexto e o paratexto), o campo lexical que emerge das notícias, o leitor hipotético a que se destina a matéria, para enfim chegarmos a uma proposta de tipologia para as personas representadas nos três jornais analisados.

\section{A morte de Guimarães Rosa na mídia brasileira}

Partindo da paradoxal ideia de que somente quando um homem morde um cachorro é que temos um acontecimento digno de ser noticiado, e para buscarmos entender as formas pelas quais um acontecimento banal (morte) é traduzido em acontecimento midiático, tentaremos, com a análise de aspectos formais e discursivos, responder à seguinte questão: quais são os recursos gráficos, narrativos e discursivos mobilizados para se construir uma matéria incitante, sobretudo quando se trata de publicizar acontecimentos biográficos, no entrelugar em que convergem fatos e ficção?
Quadro 1. Posição da matéria no espelho do jornal

\begin{tabular}{|l|l|l|l|}
\hline & \multicolumn{1}{|c|}{$\begin{array}{c}\text { O Globo } \\
\mathbf{2 0 / 1 1 / 1 9 6 7}\end{array}$} & $\begin{array}{c}\text { Estadão } \\
\mathbf{2 1 / 1 1 / 1 9 6 7}\end{array}$ & $\begin{array}{c}\text { Folha de São Paulo } \\
\mathbf{2 1 / 1 1 / 1 9 6 7}\end{array}$ \\
\hline Disposição & Página 8 & Página 18 & $\begin{array}{l}\text { Primeira página do } \\
\text { "Folha llustrada" } \\
\text { (caderno de cultura) }\end{array}$ \\
\hline $\begin{array}{l}\text { Espaço } \\
\text { ocupado }\end{array}$ & $\begin{array}{l}\sim / 2 \text { da página, parte } \\
\text { superior esquerda }\end{array}$ & $\begin{array}{l}\sim / 5 \text { da página, } \\
\text { parte esquerda }\end{array}$ & $\begin{array}{l}\sim 1 / 3 \text { da página, } \\
\text { parte superior }\end{array}$ \\
\hline
\end{tabular}

Inicialmente, notemos que a posição das matérias no espelho é sintomática das práticas editoriais: se as páginas ímpares são as que oferecem maior destaque (os anunciantes arcam com custos mais elevados para publicação nessas páginas), apenas a Folha reservou esse espaço privilegiado para a notícia fúnebre, na primeira página de seu caderno de cultura. Com um título chamativo e uma matéria instigante, esse veículo capitalizou com bastante proveito sua opção: dois terços da página serão ocupadas por anúncios publicitários. Por outro lado, o destaque dado à matéria confirma, junto ao público leitor, o engajamento do veículo para com um tema que se pretende relevante - a cultura e a literatura nacionais. Pode-se inferir que se trata de uma estratégia editorial para satisfazer o horizonte de espera do público leitor, suas expectativas com relação ao trato para com as manifestações culturais e artísticas nacionais, num contexto em que a cultura tem alto valor simbólico, e as biografias exemplares assumem um elevado valor social.

Por seu lado, em razão da hora atestada para a morte de Rosa e do horário para fechamento da edição, $O$ Globo provavelmente foi forçado a acomodar a notícia em espaço anteriormente destinado a oura matéria, numa página par, pois foi o único veículo a publicar o fato na edição do dia seguinte, uma segunda-feira. A modesta posição e ocupação de espaço terminam por atribuir um caráter de fato corriqueiro à morte do excepcional escritor. Como veremos adiante, essa condição pode talvez decorrer de uma aberta intencionalidade por parte dos editores, no sentido de escamotear a relevância da cultura e da literatura, no contexto de uma sociedade controlada pela ditadura militar.

Perspectiva semelhante é a que se encontra no espelho do Estadão, com uma pequena diferença no quesito "espaço ocupado", pois o veículo paulista, publicado na terça-feira, reserva maior extensão para sua matéria, habilmente intercalada com notas sobre outros fatos do mundo das artes.

Esses marcadores semióticos decorrem das características do público-alvo dos diferentes veículos e, com apoio em outras condicionantes editoriais, é possível neles entrever o leitor implícito nas páginas midiáticas ora em análise. 
Quadro 2. Leitor implícito

\begin{tabular}{|c|c|c|c|}
\hline & $\begin{array}{l}\text { O Globo } \\
20 / 11 / 1967\end{array}$ & $\begin{array}{l}\text { Estadão } \\
21 / 11 / 1967\end{array}$ & $\begin{array}{l}\text { Folha de São Paulo } \\
\qquad 21 / 11 / 1967\end{array}$ \\
\hline $\begin{array}{l}\text { Contexto condicionante: } \\
\text { tradição político-editorial e } \\
\text { público-alvo }\end{array}$ & $\begin{array}{l}\text { Fundação: } 1925 . \\
\text { Orientação política: direita, Alinhada à } \\
\text { ditadura militar. } \\
\text { Público-alvo: elites urbanas político- } \\
\text { econômicas (classes A-B). }\end{array}$ & $\begin{array}{l}\text { Fundação: } 1875 . \\
\text { Orientação política: direita, Próxima à } \\
\text { ditadura militar. } \\
\text { Público-alvo: elites urbanas político- } \\
\text { econômicas (classes A-B). }\end{array}$ & $\begin{array}{l}\text { Fundação: } 1921 . \\
\text { Orientação política: centro-direita, Oposição } \\
\text { branda à ditadura militar. } \\
\text { Público-alvo: elites urbanas econômicas } \\
\text { e/ou intelectuais (classes A-B). }\end{array}$ \\
\hline Peritexto: anúncios publicitários & $\begin{array}{l}\text { Propagandas de bens de elevado custo de } \\
\text { aquisição (caminhão Mercedes-Benz). }\end{array}$ & $\begin{array}{l}\text { Propagandas de bens de elevado custo } \\
\text { de aquisição (eletrola portátil Delta, Casas } \\
\text { José Silva, eletrodomésticos Sandor e } \\
\text { televisão Telefunken). }\end{array}$ & $\begin{array}{l}\text { Propagandas de bens de elevado custo } \\
\text { de aquisição (caminhão Mercedes-Benz, } \\
\text { eletrola portátil Delta). } \\
\text { Livro que narra a história da Revolução } \\
\text { Russa (1918) na perspectiva da ditadura } \\
\text { militar brasileira. }\end{array}$ \\
\hline Peritexto: matérias justapostas & $\begin{array}{l}\text { Notas sobre concertos de música erudita } \\
\text { (maestros Arthur Morelenbaum e Isaac } \\
\text { Karabtchewsky, Festival Villa-Lobos na } \\
\text { sala Cecilia Meirelles). }\end{array}$ & $\begin{array}{l}\text { Exposições comerciais de artes plásticas } \\
\text { (Alberto Guignard, pintor recém falecido, } \\
\text { então em evidência no mercado brasileiro } \\
\text { de artes, entre outros artistas). }\end{array}$ & Ausente. \\
\hline Paratexto: fotografia & Ausente. & $\begin{array}{l}\text { Rosa com sua tradicional gravata } \\
\text { borboleta. } \\
\text { Legenda: Guimarães Rosa, diplomata. }\end{array}$ & $\begin{array}{l}\text { Rosa, em seu fardão da ABL. } \\
\text { Legenda: Guimarães Rosa pronuncia seu } \\
\text { discurso de posse na Academia Brasileira } \\
\text { de Letras. }\end{array}$ \\
\hline Leitor implícito & $\begin{array}{l}\text { Dirigentes políticos e empresariais, elite } \\
\text { econômica e sociocultural: establishment } \\
\text { alinhado à ditadura militar. }\end{array}$ & $\begin{array}{l}\text { Dirigentes políticos e empresariais, elite } \\
\text { econômica e sociocultural, intelectuais: } \\
\text { establishment alinhado à ditadura militar. }\end{array}$ & $\begin{array}{l}\text { Intelectuais, elite econômica e sociocultural: } \\
\text { establishment e contestatários. }\end{array}$ \\
\hline
\end{tabular}

No jornal $O$ Globo, os anúncios publicitários e notas sobre concertos de música clássica centram-se no consumo de bens materiais e simbólicos destinados a um público de elevado poder aquisitivo. Cabe notar que as notas sobre música erudita contêm apenas elementos informativos mundanos, sem qualquer referência à dimensão estética ou interpretativa, fato que poderia sugerir a presença implícita de um leitor preocupado com aspectos intelectuais da arte. Seria possível atribuir ao leitor implícito desta matéria o seguinte bordão lançado por Oscar Wilde: "Eles sabem o preço de todas as coisas, mas o valor de coisa alguma". A cultura torna-se apenas mais um bem a ser consumido (com obrigatória ostentação): tal é o leitor implícito que emerge da articulação do jogo de co-intencionalidades em torno dessa matéria, para retomarmos as ideias de Patrick Charaudeau (2010). É interessante observar, na matéria de $O$ Globo, que esse veículo serve-se do evento fúnebre para sua autopromoção, pois informa que o recémfalecido autor publicava seus escritos primeiramente nesse veículo, e a parte central da matéria inclui longas linhas de referência ao Prêmio Walmap, promovido pelo próprio grupo Globo. Portanto, a própria notícia apresenta-se como um bem de consumo, que solicita sua autopromoção e sua autocelebração para fidelização de consumidores.

O Estadão adota uma linha discursiva convergente, mas, no lugar de notas sobre concertos, inclui informativos sobre exposição do pintor Alberto Guignard (entre outros artistas de menor renome), com ênfase para o valor de investimento financeiro (ou simbólico), em detrimento do possível valor artístico que exigiria uma nota crítica especializada. “O BNMG financiará as vendas”, informase ao leitor, com relação às obras de Guignard. O leitor implícito corresponderia a um consumidor de bens culturais que necessita acatar regras coletivas para orientar suas práticas culturais obrigatórias, que implicam um também obrigatório consumo de arte - com pouca ou nenhuma possibilidade de fruição estética. Dessas matérias acompanhadas pelos anúncios publicitários e notas para eventos culturais, deduz-se uma forte monetização das práticas culturais, para muito aquém do seu valor simbólico e estético. A foto escolhida para ilustrar o texto sobre a morte do autor reforça essa ideia: Guimarães Rosa é apresentado com sua tradicional gravata borboleta, uma evidente marca de pertencimento ao seleto segmento social daqueles que detém (e ostentam) uma posição econômica privilegiada. Em outros termos, a foto celebra o próprio leitor implícito no texto, em sua condição de membro das classes A e B - produtor e consumidor de bens culturais de prestígio (como a própria gravata em tela).

Quanto à Folha de São Paulo, no conjunto da matéria, a dimensão intelectual de Guimarães Rosa prevalece sobre o valor de mercado e sua obra. Mesmo a nota publicitária disposta junto ao texto, destinada a fazer apologia ao mercado e a apontar os aspectos negativos da Revolução Russa, acentua o lado intelectual do leitor implícito do jornal, pois se trata de indicar um livro, de promover a leitura. Cabe notar que a matéria acrescenta a essa biografia uma nota de transcendência espiritual e de misticismo, como veremos adiante. Por outro lado, a fotografia escolhida para ilustrar a matéria (Rosa em seu 
Quadro 3. Tipologia textual e título da matéria

\begin{tabular}{|c|c|c|c|}
\hline & $\begin{array}{l}\text { O Globo } \\
20 / 11 / 1967\end{array}$ & $\begin{array}{c}\text { Estadão } \\
21 / 11 / 1967\end{array}$ & $\begin{array}{l}\text { Folha de São Paulo } \\
\qquad 21 / 11 / 1967\end{array}$ \\
\hline $\begin{array}{l}\text { Tipologia textual e tom } \\
\text { discursivo }\end{array}$ & $\begin{array}{l}\text { Texto único não assinado: descritivo- } \\
\text { documental, autoria institucional. } \\
\text { Tom neutro. }\end{array}$ & $\begin{array}{l}\text { Texto em tríptico, múltipla autoria: } \\
\text { 1. descritivo-documental sem assinatura } \\
\text { autoral; } 2 \text {. didático-opinativo assinado; } \\
\text { 3. poético assinado com iniciais. } \\
\text { Tom ora neutro, ora didático, ora pessoal. }\end{array}$ & $\begin{array}{l}\text { Texto único assinado: simultaneamente } \\
\text { descritivo-documental, opinativo e poético. } \\
\text { Autoria individual. } \\
\text { Tom participativo. }\end{array}$ \\
\hline Título & $\begin{array}{l}\text { Morre Guimarães Rosa } 3 \text { Dias Depois } \\
\text { do Ingresso na Academia }\end{array}$ & Guimarães Rosa faleceu domingo & Guimarães Rosa previu a própria morte \\
\hline Destaque ao título & $\begin{array}{l}2 \text { linhas, ocupando toda a cabeça da } \\
\text { matéria, com fonte bold em negrito. }\end{array}$ & $\begin{array}{l}1 \text { linha, com espaço antes e depois do } \\
\text { título, fonte em itálico e negrito. }\end{array}$ & $\begin{array}{l}1 \text { linha, com espaço antes e depois do } \\
\text { título, fonte regular sem itálico ou negrito. }\end{array}$ \\
\hline
\end{tabular}

fardão no discurso de posse na $\mathrm{ABL}$ ), destacada no centro da página, sugere que a ideia de que o leitor implícito da Folha atribui importância ao reconhecimento da obra do escritor no plano literário, para além dos elogios de praxe que as honrarias governamentais podem acrescentar à biografia de um autor recém falecido.

Os títulos merecem aqui atenção especial. No $O$ Globo, o título da matéria evacua o aspecto literário para se concentrar no atrelamento do escritor a mais uma das instituições (ABL) que estruturam o Estado, então sob rígido controle da ditadura militar (e do jornal que ora analisamos). Do início ao fim do texto, conta-se a trajetória de construção de um "monumento", condição que se explicita no último parágrafo: a obra de Rosa é comparada ao grande monumento nacional que é Brasília. Graficamente, o próprio título da matéria já anuncia esta perspectiva: impresso em fonte bold, com linhas sólidas e proporções pétreas, o título representa simbolicamente o peso das instituições às quais Guimarães Rosa teria aderido ao longo de sua vida, no entender do jornal - ou em sua estratégia de elevar á condição de cânone uma biografia que se pretende exemplar.

Do ponto de vista semântico, o título sugere ainda que Rosa teve muito pouco tempo (3 dias) para usufruir das vantagens e prazeres decorrentes do fato de integrar e pertencer a mais essa instituição monumental. $\mathrm{O}$ título inicia-se com o categórico "morre", no presente do indicativo, tempo verbal que induz a ideia de uma ação que continua acontecendo a cada nova leitura do título um recurso poético amplamente utilizado na ficção. Essas repetidas mortes relegam o escritor, reiteradamente, a um passado revoluto, cada vez mais longínquo. Caberá ao leitor esperar o surgimento de outro indivíduo que, tal qual uma eventual peça de reposição, possa ocupar o lugar deixado vago no âmbito de um série mecânica de substituições e reposições - fato que é, aliás, explicitamente mencionado no trecho que trata da vacância da cadeira ocupada por Rosa, numa sequência natural de alternâncias. O ser humano cede lugar a um ser funcional, utilitário, substituível, descartável, com prazo de caducidade planejada, numa perfeita ordem no plano racional da sociedade industrial e mercantil, em que tudo e todos se transformam em mercadoria e peças de reposição. Nessa matéria, o Ser Humano cede seu lugar à Coisa.

No Estadão, a notícia da morte do escritor é apresentada, em seu título, como um fato corriqueiro, sem motivos para qualquer alarde ou admiração: "Guimarães Rosa faleceu domingo". A escolha do verbo e da fonte gráfica convencional atenua o impacto do acontecimento junto aos leitores. Contudo, os títulos das matérias secundárias ("Repercussão" e "O autor não se contentou com moldes convencionais") atentam para a notoriedade do escritor e para os reflexos de sua morte junto à imprensa nacional e estrangeira, sobretudo no que se refere aos representantes de instituições oficiais diversas - a exemplo de ministros, governadores e parlamentares, bem como de integrantes de instituições editoriais internacionais.

Na Folha de São Paulo, o título define o tom da matéria: "João Guimarães Rosa previu a própria morte". A ênfase centra-se na natureza inexplicável da personalidade misteriosa do escritor. A morte encontrase em segundo plano, como se fosse o desfecho de um projeto literário em construção: um escritor costuma prever a morte de seus personagens, jamais a sua própria. Por essa razão, o título é fortemente carregado de poesia, convidando o leitor a produzir sentidos para a matéria. Por coincidência (ou intencionalidade?), a fotografia, o título da matéria e o cabeçalho, simetricamente centrados na página, formam a figura de uma cruz (em cujo centro Rosa abre os braços para a posteridade), contribuindo para realçar o aspecto místico da matéria que o leitor deverá decifrar. O título não encerra Guimarães Rosa no passado definitivamente conhecido e reconhecido - a exemplo dos dois outros jornais -, mas, ao contrário, o projeta em um futuro desconhecido e a explorar. De forma sub-reptícia, o conjunto inscreve-se num certo imaginário de natureza cristã: no caminho inverso ao de Cristo (que ressuscitou no terceiro dia), Rosa entrega sua alma no terceiro dia após a posse na Academia. 


\section{Aspectos semânticos e lexicais: consolidação de uma ficção (auto) biográfica pelo jornalismo brasileiro}

Vale lembrar que, em sua última aparição pública, numa quinta-feira, 16 de novembro de 1967 , no dia preciso em que ocorreu a tantas vezes adiada posse na Academia Brasileira de Letras, Guimarães Rosa pronunciou o célebre discurso intitulado "O Verbo e o Logos", que se abre e se encerra em espiral sobre o nome do vilarejo natal do autor, Cordisburgo. Esse discurso, como de praxe, deveria apresentar um breve resumo geral da biografia contextualizada do embaixador escritor. Contudo, ele também pode ser lido como uma reverência ao universo da criação literária, embora ataviado com muitas referências explícitas à morte - como aquela que vai ocorrer, súbita e coincidentemente, três dias mais tarde. A cerimônia, que contou com a presença de Juscelino Kubitschek, expresidente da República, foi realizada com grande pompa e esmero, principalmente em razão do zelo com que o romancista poliglota se aplicou, durante mais de quatro anos, para o misterioso adiamento desse evento que anteciparia sua morte, ocorrida, precisamente, menos de 76 horas depois (cf. MARINHO, 2001, 2012).
Nessa ordem de ideias, buscaremos articular o factual com o fictício, os fatos biográficos e sua representação pela mídia brasileira, em confronto também com o magistral romance desse escritor poliglota e inovador, Grande Sertão: Veredas, pelo fato de que essa obra foi qualificada pelo próprio autor como uma "autobiografia irracional", em entrevista concedida a Günter Lorenz (cf. COUTINHO, 1983). A perspectiva que determina a presente leitura é, portanto, a de um escritor possuído pela ideia de que, por intermédio de textos literários (mas também jornalísticos), "as pessoas não morrem, eles ficam encantadas", tal como o romancista define em seu discurso, pouco antes de, ele mesmo, "ficar encantado". Passemos, portanto, ao quadro em que se dispõem o campo lexical definido por cinco lexemas, os quais estruturam os textos das matérias analisadas: instituições, morte, mistério, posteridade, literatura. Das múltiplas articulações que se operam nesse campo lexical, emergem as personas que buscamos identificar na presente pesquisa. Os números indicados entre parênteses referem-se à quantidade de vezes que o termo léxico aparece no texto, em algumas ocasiões sob forma de variantes.

Quadro 4. Campo lexical

\begin{tabular}{|c|c|c|c|}
\hline & $\begin{array}{l}\text { O Globo } \\
20 / 11 / 1967\end{array}$ & $\begin{array}{l}\text { Estadão } \\
21 / 11 / 1967\end{array}$ & $\begin{array}{c}\text { Folha de São Paulo } \\
21 / 11 / 1967\end{array}$ \\
\hline Instituições & $\begin{array}{l}\text { diplomata, concurso, Itamarati (2), } \\
\text { cônsul (2), secretaria de Estado, } \\
\text { conselheiro de embaixada, embaixadas, } \\
\text { delegações, congressos, conferências, } \\
\text { UNESCO, comissão, presidente, recinto, } \\
\text { três médicos (2), prêmio nacional } \\
\text { Walmap, homem público, patrono, } \\
\text { fundador, sucessor (2), candidato (2), } \\
\text { vaga, acadêmicos, ABL (5), salão, } \\
\text { cumprimentos, eleito, ilustres (2), } \\
\text { embaixador (2), CFC (2), ministro, editor, } \\
\text { posse (2), academia (3), sensação cívica, } \\
\text { Câmara de Letras. }\end{array}$ & $\begin{array}{l}\text { Diplomata (7), ABL (8), polícia militar, } \\
\text { secretaria, valor na literatura, ministro (4), } \\
\text { membros, CFC, governador, assessor de } \\
\text { imprensa, diretor, MIS, congresso cultural, } \\
\text { mausoléu da ABL, STM, procurador- } \\
\text { geral, letras brasileiras, ministro, Casa, } \\
\text { presidente (5), telegramas, ilustre casa, } \\
\text { governo, acadêmicos (2), secretario } \\
\text { da Educação (2), ginásio do Estado, } \\
\text { declaração, homenagem, minuta, decreto, } \\
\text { ginásio de Estado, governador (3), posse, } \\
\text { telex, fundador, chanceler, ministro, } \\
\text { Itamarati (3), Casa, câmara (2), anais } \\
\text { da casa, voto de pesar, letras nacionais, } \\
\text { parlamentares, tribuna, mérito, meios } \\
\text { literários parisienses, diretor, Editions du } \\
\text { Seuil, letras da América Latina, prêmio } \\
\text { de poesia Olivetti, Brasilia, embaixador, } \\
\text { biblioteca do palácio, divisão de fronteiras. }\end{array}$ & $\begin{array}{l}\text { burocracia, secretaria de Estado, carreira } \\
\text { diplomática (3), Divisão de Fronteiras, } \\
\text { medicina, Força Pública mineira, Academia } \\
\text { Brasileira de Letras, Cônsul, segundo- } \\
\text { secretário, conselheiro, ministro, Divisão de } \\
\text { Fronteiras do Itamarati, ministro, imprensa, } \\
\text { Ministério das Relações Exteriores, } \\
\text { diplomata (2), acadêmico (2) governador } \\
\text { (2), Secretário de Educação. }\end{array}$ \\
\hline Morte & $\begin{array}{l}\text { morte (7), sentir mal, ultima, três médicos, } \\
\text { ultima entrevista, saudoso, corpo, velado, } \\
\text { noite (5), "última visão", "o último dia", } \\
\text { "ficou a sós", "sentia-se mal, médico } \\
\text { (2), salvar, coramina, "cerrou os olhos } \\
\text { para sempre", madrugada, velório, } \\
\text { sepultamento, féretro, mausoléu dos } \\
\text { imortais, cemitério }\end{array}$ & $\begin{array}{l}\text { enfarte do miocárdio, sepultado (7), } \\
\text { cemitério, jazigo, "mausoléu destinado } \\
\text { aos imortais", velório, morte (7), } \\
\text { sepultado, noite (2), sozinho, missa, } \\
\text { urgência, médico, "a injeção de coramina } \\
\text { aplicada às pressas não chegou a surtir } \\
\text { efeito", ambulância, jazia, noite, corpo } \\
\text { (3), transladado, perda, infinita mágoa, } \\
\text { encomendado, padre, cura, igreja, féretro, } \\
\text { murchar, prantos, coveiros, camadas de } \\
\text { cimento, laje de mármore, mausoléu, } \\
\text { falecimento, imortalidade, passamento, } \\
\text { desaparecimento (2), pesar (5), } \\
\text { falecimento (2), demônio, Fausto, "tinha } \\
\text { medo de se empossar e morrer"! }\end{array}$ & $\begin{array}{l}\text { imortal jagunço, temor (3), pistas do } \\
\text { "demoníaco", constante pressentimento } \\
\text { em relação à morte, morte fatal, enfarte } \\
\text { derradeiro, setenta e duas horas antes } \\
\text { do desenlace, vida, morreu (3), pesar (2), } \\
\text { morte (3), "nos desfalca do mais alto valor } \\
\text { contemporâneo de renovação da literatura } \\
\text { nacional", "grande perda para as letras } \\
\text { latino-americanas" }\end{array}$ \\
\hline
\end{tabular}


Quadro 4 (conclusão)

\begin{tabular}{|c|c|c|c|}
\hline & $\begin{array}{l}\text { O Globo } \\
20 / 11 / 1967\end{array}$ & $\begin{array}{l}\text { Estadão } \\
21 / 11 / 1967\end{array}$ & $\begin{array}{c}\text { Folha de São Paulo } \\
21 / 11 / 1967\end{array}$ \\
\hline Mistério & $\begin{array}{l}3 \text { dias (5), "mostrou-se emocionadíssimo" } \\
\text { (2), "relutou em tomar posse" (2), três } \\
\text { médicos (2), noite (5), receio (2), "relutava } \\
\text { em tomar posse", confidenciava (2), } \\
\text { "receava tomar e falecer pouco depois, } \\
\text { missa, "contava } 59 \text { anos", mausoléu dos } \\
\text { imortais }\end{array}$ & $\begin{array}{l}\text { "ainda emocionado com a sua } \\
\text { posse","jazigo n¹3", "morreu aos } 59 \\
\text { anos de idade", noite (2), "quando } \\
\text { resolveu telefonar ao escritor Geraldo } \\
\text { França de Lima, seu amigo há } 34 \text { anos, } \\
\text { pedindo-lhe que fosse à sua casa (...) } \\
\text { para conversarem", "o escritor jazia sobre } \\
\text { seus escritos", noite, surpreenderam-se, } \\
\text { demônio, Fausto, choque tremendo, ficar } \\
\text { nauseado, impacto avassalador da notícia, } \\
\text { perturbação, assombrara, profundo } \\
\text { choque, frisson de susto, de medo e } \\
\text { perplexidade, desamparado e só, mistério, } \\
\text { tinha medo de se empossar e morrer!, } \\
\text { parecia uma superstição absurda e pueril, } \\
\text { as pessoas sorriam, superiores, quando } \\
\text { comentavam o fato, notícia } \\
\text { brutal, petrificado, siderado, coisa } \\
\text { estranha arrepiante, "até agora não } \\
\text { compreendo", "até agora estou pasmo", } \\
\text { "e desolado também". }\end{array}$ & $\begin{array}{l}\text { "previu a própria morte", vidente, } \\
\text { mago, perspectiva miraculosa dos } \\
\text { acontecimentos, simbolismo, temor (3), } \\
\text { espirito profundamente religioso, "sentir } \\
\text { um extraordinário temor reverencial } \\
\text { diante do sagrado e suas manifestações", } \\
\text { sacral, espírito, pistas do "demoníaco", } \\
\text { "profundos interiores da nossa paisagem } \\
\text { física e humana, supersticioso", "constante } \\
\text { pressentimento em relação à morte", } \\
\text { angustiante impressão, coincidência } \\
\text { impressionante, bom agoura, setenta e } \\
\text { duas horas antes do desenlace, Sagrado } \\
\text { Coração de Jesus, somente há três dias, } \\
\text { há três dias, quando um homem vem inteiro } \\
\text { pronto de suas próprias profundezas, morte } \\
\text { inesperada, atônito ante o maravilhoso. }\end{array}$ \\
\hline Posteridade & $\begin{array}{l}\text { academia (3), ABL, Machado de Assis, } \\
\text { discurso (6), imortalidade (4), Cordisburgo } \\
\text { (2), Minas Gerais, Sertões das Gerais, } \\
\text { Rio São Francisco, Rio Urucuia, última } \\
\text { entrevista coletiva, divulgação, "contava } \\
59 \text { anos", "a morte o surpreendeu em } \\
\text { plena apoteose", notícia, irradiação } \\
\text { mundial de seu nome, estudo da sua } \\
\text { obra, universidades, "os livros que } \\
\text { sobre ele se escreveram", obra perene, } \\
\text { reconhecimento, "correspondia, no plano } \\
\text { literário, à construção de Brasília". }\end{array}$ & $\begin{array}{l}\text { "mausoléu destinado aos imortais", "mais } \\
\text { de seiscentas pessoas", depoimento, } \\
\text { posteridade, discurso (2), elogio (2), } \\
\text { esplendor da solenidade, palmas, } \\
\text { admiração, memoráveis, testemunho, } \\
\text { construção de Brasília, sinopse diária, } \\
\text { resumo dos jornais, notícia (2). }\end{array}$ & $\begin{array}{l}\text { história literária, irrompeu nas nossas letras, } \\
\text { panorama literário, o nome mais prestigioso } \\
\text { de nossas letras, sucessor de Machado } \\
\text { de Assis, dimensão metafísica, vertente } \\
\text { universalista, imortal jagunço, visionário, } \\
\text { amoroso moldador de uma língua nova, } \\
\text { criou uma nova linguagem, falar novo, } \\
\text { suceder, conferiu voz e pensamento } \\
\text { aos seus personagens, imortalidade, } \\
\text { obra, liderança incontestada das letras, } \\
\text { ressonância universal, estilo de um } \\
\text { Brasil novo. }\end{array}$ \\
\hline Literatura & $\begin{array}{l}\text { "primeira palavra", discurso (6), "o } \\
\text { começo", linguajar, quinhentista, pesquisa } \\
\text { renovação (3), conquistas, literatura, } \\
\text { estreado, livro (5), poesia, despontou, } \\
\text { glória literária, editado, escritor (9), raro, } \\
\text { importante, Machado de Assis, obra, } \\
\text { debates, estudos, exegeses, exames, } \\
\text { análises, riqueza vocabular, novelas, } \\
\text { literatura (6), romance, obra (3), narrativa } \\
\text { (3), força, estória época, Riobaldo, } \\
\text { Diadorim, personagens, traduzido, } \\
\text { versão, aclamada, professores, escrever } \\
\text { (3), teses, série, estórias, contos (2), } \\
\text { vocabulários, candidato (3), ABL (4), casa } \\
\text { de Machado, "a pressão do escritor subia } \\
\text { sempre depois de } 18 \text { horas", "mostrou-se } \\
\text { emocionadíssimo", "a força do romance", } \\
\text { prêmio nacional Walmap, romances, } \\
\text { gênero, nível excepcional , composição, } \\
\text { editor, perfil, escritor, acadêmicos, } \\
\text { cumprimentos, eleito, gabinete de } \\
\text { trabalho (2), autor, ilustres, novelística, } \\
\text { raízes populares, "a morte o surpreendeu } \\
\text { em plena apoteose", glória literária, } \\
\text { estudo da sua obra. }\end{array}$ & $\begin{array}{l}\text { escritor (9), acadêmicos (5), trabalhava } \\
\text { (2), livro (5), conto, capítulo (2), figurar, } \\
\text { série, autógrafos, livrarias (3), escritos, } \\
\text { valor na literatura, valor, renovador, } \\
\text { romance (10), literatura (4), autenticidade, } \\
\text { cadeira, criação, recriação, estilo, meios } \\
\text { literários parisienses, publicavam, } \\
\text { obra (6), crítica (3), poeta, valores, } \\
\text { latino-americana, traduzidos, autor, } \\
\text { moldes convencionais, poesia, mente, } \\
\text { teóricos, arte literária, experiências, } \\
\text { vanguardas, prosa de ficção (12), } \\
\text { gênero, estético (6), conhecimento, } \\
\text { estudiosos, crítica, literária, ilustrar, } \\
\text { linguagem (5), significado, expressão, } \\
\text { pesquisas (2), autor, romancistas, } \\
\text { ideal, padrão estrutura, narrativa, ritmo, } \\
\text { mediação, depoimento, digressão, conto, } \\
\text { visão do mundo, Riobaldo, Fausto, obra, } \\
\text { moldes convencionais da poético (2), } \\
\text { criador, processo, subjetiva, perspectiva, } \\
\text { pergunta, mito universal, debates, } \\
\text { beletrismo, obra de arte, visão do mundo, } \\
\text { palavras, temas, sentido, pitoresco, ação, } \\
\text { personagens, criação artística, magia das } \\
\text { palavras, realidade autônoma, matéria } \\
\text { literária, crônica. }\end{array}$ & $\begin{array}{l}\text { literatura (4), língua portuguesa (2), escritor } \\
\text { (4), historia literária, panorama literário, } \\
\text { o nome mais prestigioso de nossas } \\
\text { letras, Machado de Assis (2), novelística, } \\
\text { escritor puro, romance brasileiro, } \\
\text { gênero regionalista, drama, tragédia, } \\
\text { Riobaldo, Hamlet do Sertão, leitores, } \\
\text { crítica (2), contos, livros (8), linguagem } \\
\text { personalíssima, simbolismo, ensaística } \\
\text { nacional, artesão da língua,escritor } \\
\text { brasileiro, dimensão criadora, Mario de } \\
\text { Andrade (2), linguagem classicizante, } \\
\text { linguagem artificiosa, arcaísmos, fabulário } \\
\text { arcaico, gênio criador, caderno de notas, } \\
\text { maravilhosos falares, personagens, } \\
\text { obra (3), escritores, poetas, criações, } \\
\text { contemplação poética, gabinete de } \\
\text { trabalho, instante criador, acadêmico (2), } \\
\text { setenta e duas horas antes do desenlace, } \\
\text { Euclides da Cunha, Guilherme de Almeida, } \\
\text { novelistas, liderança incontestada das } \\
\text { letras, autor, criatividade literária, literatura } \\
\text { nacional, cultura popular, criações, } \\
\text { inteligência literária, meios literários } \\
\text { parisienses. }\end{array}$ \\
\hline
\end{tabular}

Como se observa por meio desses quadros em que se estruturam os campos lexicais, os jornais $O$ Globo e Estadão obliteram os aspectos intelectuais da vida do romancista para acentuarem sobretudo sua posição funcional dentro do aparelho de Estado e da sociedade: um indivíduo perfeitamente integrado à máquina governamental, um cidadão patriota a serviço do seu país. Os dois primeiros jornais enfatizam a notoriedade do autor em sua vida pública de diplomata e escritor, e apresentam sua morte como uma perda para as grandes 
instituições nacionais, enaltecendo uma certa trajetória profissional pública, precisamente aquela que se espera de um cidadão "a serviço de seu país" - cordato e em nada contestatário. Sobretudo no $O$ Globo, é possível observar uma nítida tendência à domesticação do estranhamento que poderia decorrer dessa morte notável.

Por sua vez, a Folha de São Paulo notícia a morte do escritor no caderno de cultura (Folha Ilustrada), enfatizando os aspectos intelectuais relevantes do autor para a cultura e a literatura brasileiras, destacando os aspectos inovadores da literatura roseana no conjunto da literatura mundial. Aspectos poéticos da obra são privilegiados, enquanto se atenuam (ou se apagam) os traços institucionais de sua biografia, característica marcante nas duas outras matérias analisadas. $\mathrm{O}$ destaque maior é atribuído à representatividade do autor no plano cultural e literário, mas um único parágrafo, com forte destaque no centro da matéria, dedica-se a esmiuçar o mistério maior, a inquirir sobre a eventual premonição do romancista com relação à data de sua morte. A matéria acentua e dá vazão ao estranhamento, ainda que uma frase sobre a "premonição" de Rosa destine-se, talvez com efeito exatamente contrário, à domesticação do mistério: "hoje domínio da parapsicologia e de experiências cientificamente controladas"...
A interpretação do campo lexical que emerge das três matérias revela uma grande e espessa aderência das matérias às linhas editoriais dos jornais. Por um lado, $O$ Globo e o Estadão salientam a notoriedade e o reconhecimento oficial (aspectos institucionais de uma biografia); por outro lado, a Folha sublinha a expressividade e a representatividade literária (aspectos intelectuais de uma existência). Com esses dados em vista, passemos à reconstrução das personagens de ficção (personas) que emergem desses campos lexicais.

Com base na interpretação do campo lexical e dos aspectos formais e contextuais das matérias publicadas pelos veículos analisados, chegamos à proposta desse quadro para explicitar a tipologia de personas atribuídas ao romancista. A nomenclatura adotada parte de estudos publicados em língua inglesa, pois nossas pesquisas resultaram infrutíferas no que se refere a línguas neolatinas, condição que se revela sintomática no tocante aos estudos sobre "personas". Assim, no tangente a Rosa, fomos induzidos à seguinte nomenclatura no que se refere à tipologia de personas, com base em estudos publicados em língua inglesa: personas "oficial", "literária" e "íntima". Cabe sublinhar que a "persona íntima" é uma entidade fictícia e abstrata, nem sempre (ou quase nunca) coincidente com a pessoa empírica - concreta e fadada à perpétua transitoriedade, puro movimento, travessia.

Quadro 5. Tipologia de personas representadas pela mídia

\begin{tabular}{|c|c|c|c|}
\hline & $\begin{array}{l}\text { O Globo } \\
20 / 11 / 1967\end{array}$ & $\begin{array}{l}\text { Estadão } \\
21 / 11 / 1967\end{array}$ & $\begin{array}{c}\text { Folha de São Paulo } \\
21 / 11 / 1967\end{array}$ \\
\hline Persona oficial & $\begin{array}{l}\text { Diplomata e "homem público" } \\
\text { altamente conceituado entre agentes } \\
\text { governamentais de primeiro escalão } \\
\text { (ministros, embaixadores, conselheiros de } \\
\text { estado, etc.). Trabalhador. Integrado às } \\
\text { instituições nacionais. Patriota. }\end{array}$ & $\begin{array}{l}\text { Diplomata altamente conceituado } \\
\text { entre agentes públicos de primeiro } \\
\text { escalão (presidente da república, } \\
\text { ministros, embaixadores, governadores, } \\
\text { parlamentares etc.). } \\
\text { "Inestimáveis serviços ao País". Integrado } \\
\text { às instituições nacionais. }\end{array}$ & $\begin{array}{l}\text { Carreira diplomática sem relevância. } \\
\text { Saudado por um ministro e um governador } \\
\text { (cuja nota de pesar centra-se na atividade } \\
\text { poética). Pouca aderência à máquina } \\
\text { governamental. }\end{array}$ \\
\hline Persona literária & $\begin{array}{l}\text { Escritor ímpar, altamente conceituado } \\
\text { entre respeitados escritores. } \\
\text { Pesquisa vocabular. Linguagem arcaica. } \\
\text { Prosa bélica e heroica. } \\
\text { Ápice poético e monumento nacional. } \\
\text { Integrado às convenções literárias. } \\
\text { Trabalhador. Patriota. } \\
\text { Reconhecimento internacional. }\end{array}$ & $\begin{array}{l}\text { "Estilo rigorosamente pessoal". Criativo. } \\
\text { Criador de personagens e paisagens. } \\
\text { Pesquisador da cultura regional e popular } \\
\text { brasileira. } \\
\text { "Inteligência literária". } \\
\text { Brilhante, admirado e meritoso. "Profundo } \\
\text { conteúdo e transcendência universal". } \\
\text { Tema fáustico. Reconhecimento } \\
\text { internacional. }\end{array}$ & $\begin{array}{l}\text { Inovações linguísticas. Pesquisa vocabular. } \\
\text { Linguagem popular. } \\
\text { "Falar novo de raízes velhíssimas". } \\
\text { "Artesão da língua". Nova realidade. } \\
\text { Do regional ao universal. } \\
\text { Drama e tragédia. } \\
\text { Personalíssimo. } \\
\text { Paisagem física e humana. } \\
\text { Unanimidade. "Fora de série". "Sucessor } \\
\text { de Machado de Assis". Reconhecimento } \\
\text { internacional. }\end{array}$ \\
\hline Persona íntima & $\begin{array}{l}\text { Humano, religioso, sensível, emotivo, } \\
\text { cordato e dedicado à família: "homem de } \\
\text { bem". } \\
\text { Residência pessoal em endereço } \\
\text { privilegiado. } \\
\text { Viagens internacionais. } \\
\text { Amigo íntimo de poderosos. } \\
\text { Morte súbita, precoce e inesperada. } \\
\text { Respeitoso das tradições e instituições. } \\
\text { Temeroso com relação à posse na ABL. } \\
\text { Portador de alegados problemas } \\
\text { cardíacos. } \\
\text { Morte corrente e explicável. }\end{array}$ & $\begin{array}{l}\text { Intensamente amigável, extremamente } \\
\text { apreciado por familiares e inúmeros } \\
\text { amigos (célebres ou anônimos), afetuoso, } \\
\text { bondoso, fraterno, puro, apegado à } \\
\text { liberdade (?). } \\
\text { Residência pessoal em endereço } \\
\text { privilegiado. Secretária pessoal. Memória } \\
\text { extraordinária. } \\
\text { Supersticioso. } \\
\text { Temeroso com relação à posse na ABL. } \\
\text { Morte extraordinária e inexplicável. }\end{array}$ & $\begin{array}{l}\text { Modesto, supersticioso, } \\
\text { profundamente religioso, vidente, mago, } \\
\text { misterioso, visionário, intuitivo. } \\
\text { Infância marcada por conflitos com adultos } \\
\text { (logo, pouca adesão a familiares). } \\
\text { Morte precoce e misteriosa, pressentida } \\
\text { antecipadamente. } \\
\text { Temeroso com relação à posse na ABL. } \\
\text { Morte extraordinária e inexplicável. }\end{array}$ \\
\hline
\end{tabular}


No contexto da construção de personas pela mídia, vale inicialmente notar que a matéria de $O$ Globo enfatiza expressões como "sensação cívica", "seu País" (com inicial maiúscula), "homem público", "heroísmo da luta", "homem de bem": para além de uma linguagem que traz as marcas de uma cultura evidentemente machista, essa retórica de cunho cívico-militar destina-se a apresentar o escritor como modelo de cidadão patriota, cordatamente integrado às grandes instituições nacionais - família, igreja, literatura canônica e... governo militar. Constróise o retrato de um modelo a ser imitado, e logo substituído (o termo "sucessor" é igualmente frisado), em que o convencionalismo ancilar torna-se uma chave para o sucesso social, pessoal, financeiro e artístico - caminhos para se alcançar uma "irradiação mundial" e a eventual imortalidade. Cabe lembrar que a então recente e célebre "Marcha da Família com Deus pela Liberdade", de março de 1964, intensamente articulada e divulgada pelo $O$ Globo, foi uma das ferramentas para promover o golpe de Estado e a implantação de um governo militar que, em 1967, recrudesceria seus métodos de repressão, os quais em breve culminariam com o exílio de inúmeros artistas contestatários - de Caetano Veloso a Oscar Niemeyer, de Geraldo Vandré a Chico Buarque, entre outros tantos.

Nesse contexto, é necessário notar que a matéria também sublinha o fato (hipotético, sem testemunhas) de que Rosa trabalhava, ao anoitecer de domingo, quando foi acometido pelo súbito e inexplicável mal que lhe ceifou a vida. Celebra-se, nesse texto, o trabalho como chave única para o sucesso pessoal e profissional extraordinário, pois até mesmo pretensas origens populares são atribuídas a Rosa, logo ao início da matéria, quando se informa sobre seu nascimento no Sertão, com ênfase para a proximidade das ribanceiras do Urucuia, sugerindo-se que Rosa fosse originário de uma comunidade de ribeirinhos: "filho de Florduardo e Dona Chiquinha..." Como se o capital social e o capital cultural fossem alheios à trajetória dos indivíduos. Eis aí a imprensa em seu pleno exercício consciente de criar personas, para degustação por parte de seus leitores. Cabe acrescentar: degustação imitativa, pois, para retomar Gabriel Tarde, sociedade é imitação.

Por outro lado, o Estadão oferece uma matéria que se desdobra em tríptico, e cada um dos três textos abraça feixes vocabulares que engendram diferentes campos lexicais e, por consequência, distintas personas. A matéria principal, de autoria institucional (sem assinatura), escreve-se no mesmo tom cívico-institucional adotado pelo $O$ Globo, senão com a mesma intencionalidade, pelo menos com o mesmo efeito de significação. Contudo, a matéria abre espaço para uma reflexão crítica sobre aspectos poéticos da obra de Rosa, assinada por Nilo Scalzo (editor do Estadão e membro da Academia Paulista de Letras), na segunda aba do tríptico. Essa nota acessória inscreve-se integralmente no campo lexical da literatura e da posteridade, e traz uma referência a Fausto, o célebre personagem que entrega sua alma como pagamento de um pacto passado com o Cão. A última aba do tríptico é uma crônica, assinada apenas com iniciais, que se inscreve integralmente no campo lexical do mistério, e explicita a questão que circula em surdina, a pergunta que não quer calar: qual é a causa dessa morte misteriosa, três dias após um evento adiado durante quatro anos? Essa narrativa fragmentada oferece pistas isoladas de leitura que solicitam uma articulação lógica para que se chegue a um eventual sentido global. Contudo, entrega-se esse sentido ao escrutínio do leitor, evitando-se explicar o inexplicável, dizer o indizível, mencionar o nome daquele-que-não-tem-nome. Oficial, literária, íntima: nas abas desse tríptico, delineiam-se as três personas de Rosa, personagens de uma narrativa que se encerra com a lemniscata $(\infty)$, abrindo-se para o infinito de indecibilidade dos sentidos.

Ao mesmo tempo, a Folha adota uma linha mais audaciosa, pois entrega a notícia às mãos do escritor e crítico literário José Geraldo Nogueira Moutinho, em matéria assinada. Esse poeta, entre o retrato oficial e o retrato literário, insere um parágrafo no qual afirma que nas páginas de Rosa podem ser rastreadas as "pistas do demoníaco", ainda que logo se recomponha para acrescentar "no sentido primitivo e socrático". Contudo, a matéria, de forma sub-reptícia, sugere uma articulação sutil entre as três personas, induzindo o leitor a imaginar a possibilidade de um eventual pacto faustiano concluído pelo próprio autor, como explicação para seus êxitos profissionais e literários, mas também para a morte misteriosa, numa forma de "coincidência impressionante". Moutinho lança ainda outra pista interpretativa, ao dizer: "afirmou-me, como de resto o fez a vários outros amigos e confidentes, que não the parecia de bom agouro essa entrada interina na imortalidade".

A confissão sigilosa, nesse caso, destina-se a tornarse pública, pois esses "outros amigos" tem o jornalismo por profissão: Otto Lara Resende, Pedro Bloch... Ter as páginas do jornal como espaço para confessionário: que forma mais eficaz para voluntariamente se construir um leque de personas ? Eis aí a ampla consciência do próprio romancista sobre a importância das informações passadas adiante, em tom de confissão, tal como acontece no momento de sua morte: com base apenas na declaração de Rosa, a imprensa notícia que o escritor morreu no preciso instante que se debruçava sobre um suposto trabalho de criação poética, em seu escritório. O caso de Pedro Bloch, médico foniatra e escritor, nos parece exemplar: Rosa frequentava o gabinete de foniatria para consultas mais adequadas a um cardiologista, deixando aí suas confissões que mais tarde seriam então divulgadas - Bloch era então 
titular de uma coluna na revista Manchete e colaborador de $O$ Globo. Como se vê, é de grande importância para a invenção de personas o cuidadoso cultivo de uma ampla rede de relações com formadores de opinião, sempre ligados ao meio da literatura ou da comunicação midiática.

Ao fim e ao cabo, da convergência dessas matérias necrológicas emerge a simbólica imagem de um escritor que encerra sua existência terrestre precisamente sobre sua mesa de trabalho, sobre seus escritos, em meio a seus livros - entre os quais é preciso notar, en passant, a presença de três exemplares dessa obra prima que é Fausto, de Goethe.

\section{Considerações finais}

É no contexto desse fato noticiado com grande destaque pela imprensa nacional que, interrogando as imbricações entre as dimensões fáticas (efeitos de verdade) e fictícias (efeitos poéticos) presentes nas matérias dos três jornais selecionados, foi possível identificar, em um primeiro momento, os índices formais, lexicais e semânticos que estruturam o processo de construção de uma ficção biográfica. Nessas páginas necrológicas do jornalismo brasileiro, as múltiplas personas de Rosa se entrelaçam na construção da narrativa jornalística, levando à emergência de uma derradeira persona que, neste trabalho, batizamos como "persona íntima".

Com base nesse estudo, pode-se inferir que o jornalista, em sua condição privilegiada de formador de opinião - e dado o papel dos media como detentores do monopólio da história, como bem problematizou Pierre Nora (1972) - é responsável pela seleção, tratamento, narrativização e difusão de fragmentos semânticos que espelham uma certa parcela de realidade. Por esse viés, o jornalista é também responsável por cristalizar certas visões de mundo ou representações (personas) de pessoas públicas, com esteio na articulação e transposição de discursos provenientes de outras instâncias discursivas. No caso da morte inexplicável de Guimarães Rosa, a responsabilidade do jornalista é redobrada: a notícia deve induzir a produção de sentidos, para que a própria vida (ou morte) também faça sentido. Afinal de contas, tomar posse na ABL com quatro anos de protelação e morrer precisamente três dias depois é, no mínimo, incongruente: o fato revela forte aderência com narrativas ficcionais, sobretudo na esteira aberta pelos relatos em torno do personagem de Fausto.

É curioso também notar que, no famoso discurso de posse, Rosa distribui dez referências explícitas à morte $\mathrm{e}$ nada menos que seis referências a Getúlio Vargas, cujo falecimento resulta de uma opção voluntária executada em 1954, dois anos antes da publicação de Grande Sertão: Veredas. Todos conhecemos de cor a carta-testamento de
Vargas, com esta frase que se tornou um monumento da história nacional: "Serenamente dou o primeiro passo no caminho da eternidade e saio da vida para entrar na história".

Como um demiurgo de si mesmo, de seu personagem de autoficção biográfica, o romancista embaixador, autor de seu próprio enredo ficcional (e, talvez, de seu próprio desenlace final), demonstra uma rara capacidade de conceber e materializar o seu próprio destino, de antecipar e influenciar os discursos que tentarão ulteriormente explicar essa trajetória, atribuindo uma dimensão mágica para essa biografia ímpar integralmente fabricada por meio da palavra. Esse personagem de Rosa seduz a atenção do leitor para muito além do último capítulo, do desfecho enigmático - e permanece em nossa imaginação e nosso imaginário, em ressonâncias múltiplas e oníricas, que são consolidadas, em diferentes níveis poéticos, pelo tom adotado à época nos textos jornalísticos analisados, conforme se demonstra neste estudo.

É possível concluir que os relatos literários e autobiográficos de Guimarães Rosa são ferramentas textuais através das quais o romancista, aos olhos do público leitor, constrói gradualmente diferentes versões de suas personas, sobretudo a literária e a íntima. No silêncio e no vazio que Rosa deixou ao empós de sua morte enigmática, suas palavras em breve vão começar a se recombinar no discurso da imprensa escrita, para criar histórias contraditórias, enredos inexplicáveis, intangíveis personagens de ficção.

\section{Referências}

BERGER, Christa. Jornalismo na comunicação. In: WEBER, Maria Helena; BENTZ, Ione; HOHLFELDT, Antonio (Org.). Tensões e objetos da pesquisa em comunicação. Porto Alegre: Sulina, 2002.

BIRD, Elizabeth; DARDENNE, Robert. Mito, registo e 'estórias': explorando as qualidades narrativas das notícias. In: TRAQUINA, Nelson (Org.). Jornalismo: questões, teorias e 'estórias'. Lisboa: Vega, 1993.

CORNU, Gérard; RUELLAN, Denis. Technicité intellectuelle et professionnalisme des journalistes. In: Réseaux. Dossier: les conventions. v. 11, n. 62, 1993, p. 145-157. Disponível em: <http://www.persee.fr/doc/reso_0751-7971_1993_ num_11_62_2585>. Acesso em: 25 set. 2016.

CORNU, Daniel. Journalisme et la vérité. In: Autres Temps. Cahiers d'éthique sociale et politique. v. 58, n.1, p.13-27, 1998. Disponível em: <http://www.persee.fr/doc/chris_075327761998 num 581 2041>. Acesso em: 25 set $201 \overline{6}$.

COUTINHO, Eduardo de Faria (Org.). Guimarães Rosa. Rio de Janeiro: Civilização Brasileira, 1983.

FRANÇOIS, Anne Isabelle; TRAN-GERVAT, Yen-Maï. Guide pratique des exercices comparatistes. Paris: Presses Sorbonne Nouvelle, 2010. 
HALL, Stuart. Codage/décodage. In: Réseaux. Les théories de la réception. v. 12, n. 68, 1994, p. 27-39. Disponível em: $<$ http://www.persee.fr/doc/reso_0751-7971_1994_num_12_ $68 \_2618>$. Acesso em: 30 set. 2016.

GOFFMAN, Erving. Os quadros da experiência social: uma perspectiva de análise. Petrópolis: Vozes, 2012.

JUNG, Carl Gustav. The Archetypes and the Collective Unconscious. Princeton: Princeton University Press, 1981.

JUNG, Carl Gustav. Two Essays in Analytical Psychology. Princeton: Princeton University Press, 2014.

LAGE, Nilson. Teoria e técnica do texto jornalístico. Rio de Janeiro: Elsevier, 2005.

LITS, Marc. Personne privée, personnage public. In: Communication [En ligne]. v. 20, n. 2, p. 9-24, 2001. Disponível em: <http://communication.revues.org/6497>. Acesso em: 12 ago. 2016.

LYRA, Pedro. O real no poético. Rio de Janeiro: Cátedra, 1980.

MARINHO, Marcelo. Grande Sertão: Veredas - Lectures critiques et approche stylistique. Contribution à l'étude de la poétique de l'Enigme. Villeneuve d'Ascq: Presses Universitaires du Septentrion, 2001. 638 p.

MARINHO, Marcelo. GRND SRT : vertigens de um enigma. Campo Grande: UCDB/Letra Livre, 2001.

MARINHO, Marcelo. João Guimarães Rosa. Paris: L'Harmattan, 2003.

MARINHO, Marcelo. João Guimarães Rosa, "autobiografia irracional" e crítica literária: veredas da oratura In: Letras de Hoje, Porto Alegre, v. 47, n. 2, p. 186-193, abr./jun. 2012. Disponível em: <http://revistaseletronicas.pucrs.br/ojs/index. php/fale/article/view/11315>. Acesso em: 12 ago. 2016.

MEDINA, Cremilda. A arte de tecer o presente: narrativa e cotidiano. São Paulo: Summus, 2003.

MOTTA, L. G. Análise pragmática da narrativa jornalística. In: Congresso Brasileiro de Ciências da Comunicação, v. 28, p. 05-09, 2005.

MOUTINHO, José Geraldo Nogueira. Guimarães Rosa previu a própria morte. In: Folha de São Paulo. Folha Ilustrada. São Paulo, 21 nov. 1967. Disponível em: <http://media.folha.uol. com.br/ilustrada/2008/11/21/ilustrada-21 11 1967.pdf $>$. Acesso em: 12 ago. 2016.

NORA, Pierre. L'événement monstre. In: Communications, 18, 1972. L'événement. p. 162-172. Disponível em: <www.persee. $\mathrm{fr} / \mathrm{doc} / \mathrm{comm}$ 0588-8018_1972 num_18_1_1272>. Acesso em: 12 ago. 2016.

OLINTO, Antonio. Jornalismo e literatura. 2. ed. Porto Alegre: JÁ, 2008.
OLYMPIO, José (Ed.). Em memória de Guimarães Rosa. Rio de Janeiro: José Olympio, 1968.

RICOEUR, P.. Temps et récit. 1. L'intrigue et le récit historique. Paris: Seuil, 1983.

RODRIGUES, Nelson. O óbvio ululante: primeiras confissões. São Paulo: Companhia das Letras, 1993.

ROSA, João Guimarães. O Verbo e o Logos. Discurso de posse na Academia Brasileira de Letras. Pronunciado em $16 \mathrm{de}$ novembro de 1967. In: OLYMPIO, José (Ed.). Em memória de Guimarães Rosa. Rio de Janeiro: José Olympio, 1968. p. 55-87. Disponível em: <http://www.academia.org.br/academicos/joaoguimaraes-rosa/discurso-de-posse>. Acesso em: 12 ago. 2016.

ROSA, João Guimarães. Grande sertão: veredas. Rio de Janeiro: Nova Fronteira, 1993.

ROSA, Vilma Guimarães. Relembramentos: João Guimarães Rosa, meu pai. Rio de Janeiro: Nova Fronteira, 1983.

$\mathrm{S} / \mathrm{N}$. Guimarães Rosa faleceu domingo. In: $O$ Estado de $S$. Paulo. São Paulo, p. 18, 21 nov. 1967.

$\mathrm{S} / \mathrm{N}$. Morre Guimarães Rosa 3 Dias Depois do Ingresso na Academia. In: O Globo. Rio de Janeiro, p. 8, 20 nov. 1967.

SILVA, Gislene. Jornalismo e construção de sentido: pequeno inventário. In: Estudos em Jornalismo e Midia, Florianópolis, v. 2, n. 2, p. 95-107, jan. 2005. Disponível em: <https:// periodicos.ufsc.br/index.php/jornalismo/article/view/2145>. Acesso em: 25 set. 2016.

TRAQUINA, Nelson. Teorias do Jornalismo: porque as notícias são como são. Vol. 1. Florianópolis: Insular, 2005.

TRAQUINA, Nelson. Teorias do Jornalismo. A tribo jornalística - uma comunidade interpretativa transnacional. Vol. 2. Florianópolis: Insular, 2008.

TUCHMAN, Gaye. Making News by Doing Work: Routinizing the Unexpected. In: American Journal of Sociology, v. 79, n. 1, p. 110-131, jul. 1973. Disponível em: <http://www.jstor.org/ stable/2776714>. Acesso em: 25 set. 2016.

WINDEN, Jesse van; BARTHOLOMEW, Angela. IMPOSE ENACT - The Artist's Persona. Editorial. Kunstlicht, Amsterdam, v. 36, n. 3, p. 7-19, 2015. Disponível em: <http:// www.tijdschriftkunstlicht.nl/impose-enact/editorial/>. Acesso em: 25 set. 2016.

WOLF, Mauro. Teorias da Comunicação. Lisboa: Presença, 2002 .

Recebido: 01/11/16

Aprovado: 09/04/17

Contato: camilam.cesar@gmail.com biografia@gmail.com 